\title{
Market-Oriented Regulation of Environmental Problems in the Netherlands
}

\author{
GJALT HUPPES and ROBERT A. KAGAN *
}

\begin{abstract}
Two functioning regulatory tax programs in The Netherlands indicate certain conditions under which such frequently-advocated but infrequently-adopted regulatory strategies can be successfully implemented. A flat fee on oxygendemanding substances in industrial effluents, introduced in 1970, has been very successful, stimulating a 90\% reduction in pollution and a search for cost-effective abatement measures. However, a recently-enacted law aimed at agricultural pollution, using a combination of direct controls and taxes on polluting inputs, has led to resistance and is not likely to be very successful. Based on these programs, regulatory taxes seem more likely to be politically and technically feasible when (a) emissions can be monitored economically; (b) the relation between emissions and environmental harm is relatively uniform and predictable; (c) implementing agencies have the technical competence and strong political and economic incentives to monitor and tax strictly; (d) the regulatory taxes apply uniformly to all sources of pollution; (e) economic efficiency is strongly valued in environmental policymaking.
\end{abstract}

\section{INTRODUCTION}

Market-oriented solutions to environmental problems have been proposed by economists since the 1920's, when Pigou proposed levying taxes on hazardous emissions. Governments rarely have adopted such recommendations, however. Market-oriented regulatory mechanisms, when employed, have been used mainly to introduce a little flexibility into systems of direct (technology mandating) regulation of emissions sources, as in the case of the U.S. Environmental Protection Agency's 'bubble' policy. ${ }^{1}$ Few truly ambitious experiments with market-oriented mechanisms have occurred, partly because of political objections, partly because of the complexities of setting and levying appropriate emission taxes. Consequently, little knowledge has accumulated about the environmental and economic effects of market-oriented programs and about the conditions that support or detract from effective implementation. ${ }^{2}$

From this standpoint, the Dutch experience with market-oriented regulatory controls is instructive. The Netherlands has implemented a comprehensive effluent-charge program that has significantly reduced harmful waste-water discharges from industrial sources. The charges have been used

* The authors thank Eugene Bardach and John Dwyer for their comments on an earlier version of this article.

LAW \& POLICY, Vol. 11, No. 2, April 1989

(C) 1989 Basil Blackwell

ISSN $0265-8240 \$ 3.00$ 
mainly to finance public waste-water treatment facilities, which have further reduced pollution. Pre-existing regional Water Boards have been able to handle monitoring and implementation of the effluent charge system.

Market-oriented regulatory techniques have been less effective, however, in coping with another Dutch environmental problem. Pollution from agricultural sources, which has escaped effective regulation in many nations, has been particularly acute in The Netherlands. Intensive agriculture has led to very high dosage of artificial fertilizer, but low effective usage. Intensive animal husbandry, based to a large extent on imported fodder, has generated an enormous amount of manure, releasing excessive ammonia, nitrate and phosphorus compounds into the environment. Agriculture now threatens the quality of surface waters and of ground water used for drinking, and is a major source of acid rain in the Netherlands ${ }^{3}$. The Dutch government responded by enacting a complex regulatory scheme. The program imposes specific limits on manure use by individual farms. Manure banks are to be established for the transfer of excess manure to less contaminated areas and for the treatment of manure. The costs of the system are financed by progressive taxes both on fodder and on the number of manure producing animals above a certain number per acre. The program came into operation in 1987 and its effects have not yet been measured. But it has engendered considerable opposition from Dutch farmers, and does not seem likely to succeed as well as the effluent charge system.

In this article, we will analyze why market-oriented regulatory methods adopted to control industrial water pollution in the 1970s appear more effective than those adopted to control agricultural pollution in the 1980s. We begin by discussing the problems that have limited the enactment of market-oriented regulatory schemes in general. Succeeding sections describe the two Dutch programs. A concluding section summarizes the differences, discusses the implications for development of market-oriented regulatory schemes, and presents a preliminary sketch of an approach to adapting emissions-fees to recalcitrant regulatory problems like agricultural pollution.

\section{MARKET-ORIENTED INSTRUMENTS FOR ENVIRONMENTAL POLICY}

Because environmental quality is a collective good, private demand for pollution control will always fall short of a socially desirable level. Only the political process can guarantee adequate demand for environmental quality. That demand can be expressed in many ways, but most commonly it has taken the form of governmental pollution control regulations specifying the kinds of control technologies that must be installed by regulated firms.

Economists have argued, however, that the demand for environmental quality should be expressed in the form of taxes or charges on pollution and 
other environmentally harmful side effects of economic activities. The argument by now is familiar: production of the mandated level of pollution control, like the production of other goods and services, usually can be accomplished most efficiently by harnessing the private profit motive and existing market mechanisms. By imposing taxes on pollution, it is argued, each polluting enterprise will be motivated to seek the most efficient methods of reducing its emissions, avoiding the wasteful expenditures that can occur when government imposes uniform abatement rules on a wide variety of production processes, or, as is common in The Netherlands, specifies for each enterprise the techniques to be used or the maximum emissions allowed. By decentralizing decision-making to private firms, moreover, the pollution tax approach may spare the government the delays of developing (and in the U.S., defending in court) mandatory regulations for hundreds of different enterprises, while minimizing the complaints of favoritism and bureaucratic unreasonableness that sometimes attend the enforcement of detailed regulations (Bardach and Kagan, 1982: Ch. 10).

Given these apparent advantages, one might wonder why market-oriented instruments like pollution fees have not been the prevalent mode of attacking environmental problems in market economies. First, when pollution sources are numerous and measurement is difficult, monitoring emissions, the basis for levying the tax, may be impractical. Since it is difficult to determine who throws old cadmium batteries into municipal dumps, how much nitrogen oxide is emitted by each automobile, and even how many hydrocarbons are emitted by the scores of point sources in a massive oil refinery, assessing the correct tax for such emissions in a legally defensible manner may be impossible or extremely costly. Direct regulations that prescribe the use of certain control technologies or totally ban potentially polluting inputs may seem easier to enforce.

Secondly, because a given volume of emissions has different environmental effects in one location than it has in another, a uniform tax often would create unacceptably unequal results. Saline compounds dumped into a river near its entrance to the sea are less harmful than the same quantity dumped far upstream. A uniform tax, set high enough to induce clean-up by the upstream source, would compel wasteful control expenditures by the downstream source. Setting emissions charges in relation to environmental harms, however, would require enormously complicated rules, differentiated not only by substance, but also by place, time, and concentration of emissions. Attempting to create an optimal tax system, therefore, would complicate, delay and politicize the fee-setting and monitoring process.

Third, pollution taxes can engender political problems. They encourage large emissions reductions by enterprises that can do so at low cost, but small or no reductions by enterprises at which, for technical reasons, the costs of control exceed the emissions taxes. While this is an economically efficient result, if the sulphur emanating from a neighboring factory irritates your eyes, it is small solace to know that a sulphur emissions tax produced 
larger reductions in pollution at most other factories, located in other towns. Increasing the tax on the factory in your town to meet political demands for equal environmental results would not only create unequal (and hence politically vulnerable) tax rates but would recreate the administrative difficulties mentioned in the preceding paragraph. Public officials, accordingly, generally have preferred to specify equal minimum levels of environmental quality everywhere, implemented by uniform emissions limits or control technologies for very many activities.

Fourth, the environmental effects of a tax may be difficult to predict. Because polluting actions arise from a variety of productive activities, each subject to a complicated array of economic incentives, it is difficult to ascertain how high taxes on polluting actions need to be in order to deter them. Setting them very high might stop pollution, but also close down socially valuable enterprises, and vice versa.

Despite these difficulties, the changing agenda of environmental regulations suggests a reconsideration of market-oriented instruments. Traditionally, public attention has focussed on localized environmental problems: a factory spoiling its neighbors' air, an offshore oil rig contaminating a coastal nature preserve, or a municipal dump with leaking drums of hazardous chemicals. In the past decade, many of the most acute, concentrated environmental problems have been attacked, and in many cases brought under control, partly as the result of aggressive direct regulation, partly as the result of advances in knowledge and control techniques. Most major corporations and public works projects now evaluate planned developments in terms of their direct environmental impacts, if only to speed the process of obtaining necessary permits.

More diffuse sources and effects of pollution, however, pose harder control problems. Emissions from households (including motor vehicles) and household refuse now constitute a much higher proportion of total emissions than they did 20 or 30 years ago. In consequence, even though concentrated emissions of sulphur and nitrogen oxides that pose direct local health hazards have been sharply reduced in western countries, the overall amount of these pollutants emitted into the atmosphere has not changed substantially in most countries.

Moreover, small increments of locally non-hazardous pollution can have cumulative far-reaching environmental impacts. Fugitive chlorofluorocarbons (CFCs), used as refrigerants, foaming agents and solvents because of their stability and very low toxicity, drift to the stratosphere, eroding the ozone layer that shields the living world from ultraviolet radiation. Cumulative emissions of $\mathrm{CO}_{2}$ and hydrocarbons from agriculture, industry, traffic, and households threaten significant changes in the global climate. Acid rain, stemming from many sources, spreads over hundreds or thousands of kilometers, across national borders. Even for problems that may appear local, such as accumulation of heavy metals in harbor sludge, the origin of the problem often has been found to be scattered emisșions of those metals far upriver. 
In view of the diffuse origins of these types of environmental pollution and the increasingly complex chains of causation, often across national boundaries, it becomes more difficult for governments to devise local control measures that are politically acceptable, effective and responsive to differences in local economic and technical circumstances. That is precisely the appeal of financial instruments like emissions taxes. They can operate at the national or even international level, shifting incentives away from the use of environmentally dangerous substances and toward cost-effective control mechanisms, but at a pace that is responsive to local conditions and in a way that may be less politically manipulable than direct regulation. Uniform tax rates would seem to provide more assurance against local or regional favoritism than locally-administered permit systems. Yet decisionmaking would remain decentralized and adaptive: emissions taxes shift producers' incentives away from use of potentially dangerous substances and toward less-polluting production methods and cleaning technologies, all in ways that are cost-effective in light of local conditions.

But under what conditions can pollution charges actually be enacted? And can they be effectively administered and work as promised? Two Dutch pollution control programs suggest some tentative answers.

\section{TAXING INDUSTRIAL WATER POLLUTION IN THE NETHERLANDS}

In the late $1950 \mathrm{~s}$ and the $1960 \mathrm{~s}$, after the long postwar years of austerity and economic reconstruction, Dutch economic growth finally accelerated. Agriculture-based businesses and the chemical industry prospered. Environmental problems were not prominent on the political agenda. Waste water treatment facilities in the strawboard industry were abandoned to reduce operating costs. ${ }^{4}$ Only locally acute pollution from metal and chemical plants received some attention. Emissions that were not immediately toxic, such as organic wastes from the growing agro-industry, generally were ignored, as were discharges from municipal sewage systems serving a rapidly growing population. ${ }^{5}$ Ultimately, the combined emissions from industry, private households and agriculture depleted the oxygen content of many of the surface waters, canals and ditches that pervade the low-lying Dutch countryside. Fish, marine animals, plants and algae died, causing offensive odors. In areas with potato flour and strawboard industries, bio-gas production from rotting waters was so intense that residents were sickened. Some water-filled ditches actually could be set afire. Public opinion became supportive of more aggressive and more costly regulation.

\section{A. THE ACT ON THE POLLUTION OF SURFACE WATERS (1970)}

The Act on the Pollution of Surface Waters (WVO) was enacted in November 1969 and became effective in 1970. The Act called for construction of public waste water treatment facilities, the upgrading and 
extension of sewering systems, and mandatory permits to govern discharges from industrial sources, which would be compelled to install in-plant treatment systems and/or link up to public sewer and treatment facilities. The public installations were to be financed via emissions charges imposed on effluents (measured in terms of oxygen demand) discharged into sewer systems or into surface waters. In contrast to pollution from industrial sites, discharges from individual households and very small firms would not be individually monitored and charged; these would each pay a flat fee. Responsibility for the administration of the Act-including specifying the terms of industrial permits, designing and operating treatment facilities, setting and collecting the emissions charges-was delegated mainly to preexisting regional water management boards, the "Waterschappen". The parliamentary vote for the Act was virtually unanimous. ${ }^{6}$

In view of the usual political objections to pollution taxes, why in this case were emissions charges successfully enacted and, as we shall see, successfully enforced? With respect to enactment, the answer, we think, lies partly in the way the charges were formally justified-not as a device to produce the socially optimal amount of pollution, as economic analysts would put it, but as an equitable way of financing the construction of sewers and treatment facilities. If pollution abatement facilities must be built, the Act seemed to say, polluters should pay-both householders (as a flat fee) and industrial sites (in proportion to the amount of their wastes).

The authors of the Act, as a government official intimately involved in the design and passage of the Act told us, both expected and intended that effluent fees would also have a regulatory effect, prodding industrial polluters to devise efficient effluent-reduction systems. But the amount of the tax, under the Act, was to be based on the revenue requirements for specific public water treatment installations, thus side-stepping the far more debatable task of determining precisely how high the tax must be to produce a socially optimal level of water quality. By setting high standards for purification by public plants, costs and thus fees would be high. Also, discharges not cleaned publicly but emitted directly would be taxed, underlining the regulatory intention.

According to the same official, there was virtually no opposition expressed by industrial groups or other private organizations. The Dutch government; as usual, had done its homework. Beginning in the late 1950s, officials had undertaken a systematic analysis of water quality management systems in other countries. Their carefully researched proposal drew in part on the model provided by the "Ruhrverband," a West German regional agency that apparently had been successful in dealing with flood control, water quality, and drinking water production in the industrialized Ruhr Valley. Some Dutch industrialists expressed fears that heavy emissions charges would jeopardize their competitiveness vis- $a$-vis foreign competitors. But industry as a whole did not protest, apparently accepting the politically popular "polluter pays" principle, and being content that house- 
holds, with total emissions about $20 \%$ less than the industry total, would be taxed on the same basis. Some organizations of industrialists, moreover, were granted places on the governing boards of the Waterschappen, traditionally dominated by farmers.

Opposition from households was heard only after the collection of taxes actually started, resulting in a reduced fee for one person households. The only significant opposition came from municipal governments upset about the loss of autonomy in regulating water quality. But some municipalities, too, were given seats on the Waterschappen boards, and the City of Amsterdam was granted Waterschap-like status under the Act.

There was one additional potential source of opposition that did not materialize. Farmers constitute a very potent political constituency in The Netherlands. Although agricultural run-off, laden with fertilizer and manure, now can be a significant source of water pollution, farmers were exempted from the permit system and effluent charges (except in the case of major point emissions, such as pumping manure directly into ditches or canals, which is strictly forbidden). Partly, this exemption may have reflected the fact that farm emissions were not yet viewed as a major contributor to bad water quality. But it also may have reflected the important role that the farmer-dominated Waterschappen played in planning the law and the crucial role they were expected to play in its implementation.

\section{B. THE WATERSCHAPPEN AND THE IMPLEMENTATION PROCESS}

The Dutch Waterschappen reflect a long tradition of local, democratic initiative in land reclamation and in flood control. In the Middle Ages, the watery Low Countries, ecologically inhospitable to large estates, did not develop a feudal system, and central government remained weak until modern times. Water management organizations, which gradually dyked, drained and ditched much of the central and western parts of the country, were primarily cooperative organizations of local small landowners. Representation, taxes and payment in kind were based on the relative size of their holdings, or similar measures. While the Waterschappen maintained local dykes, canals, sluices and pumping stations, larger regional bodies were formed for larger-scale tasks, such as maintenance of long sea-dykes; the governing body of these larger "Hoogheemraadschappen" (also called Waterschappen) was and still is staffed mainly by representatives of local Waterschappen.

In the 19th Century, through a new administrative body, the Rijkswaterstaat ('Wateraffairs of the Kingdom'), the central government assumed responsibility for defenses against the sea and major rivers, and for construction and maintenance of major canals. But the Waterschappen retained their primary powers. Owners of ditches and smaller canals have to maintain their waterways according to Waterschap regulations, enforced by a yearly inspection, the schouw (show). Landowners' taxes pay for the 
expenses of the Waterschap, and a majority of landowners still elects the governing boards.

With enactment of the national water pollution control act in 1970, the Waterschappen, with their respected administrative systems, were the logical choice for building the water-treatment plants and sewer systems, as well as for administering permit-based controls on industrial effluents. Moreover, with established systems of taxation, the Waterschappen seemed the appropriate authorities to tax discharges of polluted water. Similarly, the national Rijkswaterstaat was authorized to tax discharges to larger waters under its control, not only by industrial sources but also by the treatment facilities of the Waterschappen.

Many American environmentalists and academic analysts, upon learning of the highly decentralized nature of the Dutch system for taxation, negotiation of permits, enforcement, and construction of treatment plants - there are 40 independent units-would be skeptical about its likely effectiveness. Local administrators, it would be argued, probably would give in to corporate polluters' technical and economic arguments and get tied up in endless permit negotiations, applications for exceptions, or disputes about correct monitoring of discharges. The accommodativeness of local regulation, after all, is why national governmental action came to be regarded as the sine qua non of effective pollution control in the U.S. That, however, has not been the Dutch experience.

To be sure, some important tasks were performed at a more centralized level. The national Rijkswaterstaat earlier had established an institute (the "RIZA") for water quality issues. RIZA coordinated the formulation of the Act and later, its administration. Together with a central body of the Waterschappen (the "Unie van Waterschappen"), the Rijkswaterstaat trained local Waterschap officials for their new tasks, established uniform methods of water quality measurement, and developed general policies for issuing industrial permits and for the pace of construction of treatment plants.

The primary implementation, however, was local. Waterschappen officials visited industrial firms, of fering assistance in formulating reduction schedules, as a first step toward issuance of permits. Their approach seems to have been consultative, rather than legalistic and deterrence-oriented. But they were also vigilant. In terms of monitoring effluent levels, Waterschappen officials, already familiar with all the pipes and ditches leading into their waters, established tight information control quite easily. Finally, because the primary incentive for installation of controls came from the tax, which, generally speaking, would decline as more was spent on new installations, Waterschap officials did not, like American officials, get embroiled in arguments and delaying litigation concerning the legal necessity for particular control technologies. To minimize the tax, most firms were open to any advice on how to reduce their emissions. 


\section{EFFECTIVENESS}

How well did it all work? Generally, the steeply rising pollution of the 1960 s has been halted and even reversed. Between 1970 and 1985, as indicated by Figure 1, waste water pollutants emitted by industrial sources, measured in terms of oxygen demand, decreased by more than 70 percent. The remaining 30 percent is partially cleaned by diversion to public treatment plants.

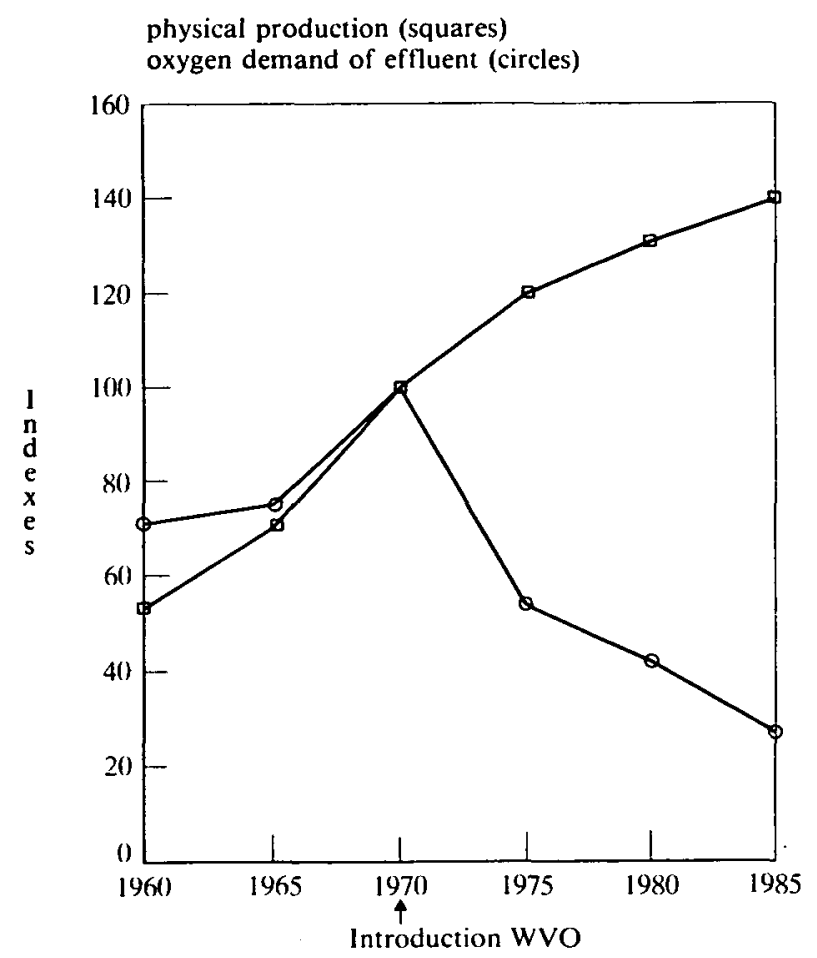

Source: Bressers (1988) and CBS (1988)

Figure 1 Indexes of Industrial Production and Effluent in The Netherlands, 1960-1985

To what extent can these striking reductions in industrial pollution be attributed to the effluent tax? Such questions normally are difficult to answer. The high costs of the public water purification facilities led to a tax level for industrial sources that would seem high enough to exert a powerful influence on industrial decision-making. But other factors may have been important, too, including the mandatory permit requirements and ongoing economic pressures to modernize facilities. Fortunately, the decentralized implementation of the program created a unique opportunity for statistical analysis, seized in an impressive manner by Bressers (1983) and later by 
Schuurman (1988). Because different Waterschappen undertook different levels of clean-up with different costs, there were differences in the level of the tax among the various administrative units. Their enforcement methods, however, were similar, because of collectively developed strategic approaches and central training of personnel involved in implementation. Bressers (1983, 171-175) thus could analyze how differences in clean-up effectiveness among Waterschappen correlated with differences in tax level. The association between the two was very strong $(r=.86)$. It improved (to $r=.92$ ) when Bressers left out of the analysis two special cases where the commercial fortunes of single companies, for reasons unrelated to the Act, determined the course of emission levels. Many other possible explanations were sought but none could explain the strong match between emission reduction and tax level. Schuurman undertook a similar analysis, not at the level of administrative units but of individual firms. His results point to a similar conclusion, that the taxes have been the main force in emission reduction by firms, with some differentiation based on sectoral background and local circumstances.

Interestingly, to Waterschappen personnel, the relationship between tax levels and clean-up effectiveness was not readily apparent, perhaps because within each jurisdiction only one tax level prevails. Their experience, they told Bressers, was that the firms were mainly very cooperative, attended to of ficials' suggestions concerning emission reduction, worked out their own plans for still further reductions, and generally complied with the agreed levels of emission reduction. The subjective impression of Waterschappen personnel was that their own technical knowledge of the firms, the reasonableness of their demands, and their personal persuasiveness determined the outcome of the negotiations. Bressers' findings of different results, depending on the amount of charges, suggests otherwise. The Waterschappen's consultative approach may have been an important factor, however, in the speed with which firms changed their emission behavior.

Unfortunately, firm-level data on tax levels and on clean-up costs, which together might make measuring cost-effectiveness possible, generally are not available. One example, however, may give an impression of the incentives generated by the tax and also of the general difficulties in measuring cost-effectiveness.

\section{A CASE STUDY}

Gist-Brocades is a Dutch-based multinational corporation; its primary activities are in biotechnology. The firm started in the 19th century as a producer of yeast and alcohol but now makes a wide range of products including enzymes and pharmaceuticals. Its headquarters is in Delft, a historic town between the Hague and Rotterdam. The enterprise also was one of the larger polluters in the area. Without manufacturing process changes or extra waste water treatment, it would have had to pay annual 
emission taxes of about $\$ 10,000,000$, which would have effectively eliminated all profits. Something had to be done, as the head of the firm's Environment Department recently stated (Lourens, 1987).

The Company's first approach was to consider installation of internal waste-water treatment facilities, thereby avoiding the tax. But according to initial estimates, this would cost as much as the tax. The search clearly had to go further. Gist-Brocades then undertook a more fundamental analysis of operations, considering all inputs, processes, and outputs. This physical and economic analysis focussed not only on current emission reductions but also on probable long-term changes in product markets, raw materials and production processes. Since these projections called for heavy productionenhancing investments over a prolonged period of time, the firm negotiated a postponement of its tax liability so that production investments could be financed and coordinated with emission-reduction measures. In a fifteen year period, Gist-Brocades reduced waste water emissions by a remarkable $92 \%$, while at the same time increasing commercial output substantially. They now pay annual emission taxes of about $\$ 1,000,000$, based on the usual rates (which is even less in 1970 dollars).

Because Gist-Brocades' emission reductions were realized as part of broader process-integrated modifications, no discrete portion of its investment costs can be attributed to the effluent tax policy. And there is no way, at the plant level, to calculate the resulting environmental benefits, so as to make an overall cost-benefit calculation possible. ${ }^{7}$ One can conclude from this example, however, that effluent taxes can have a profound effect on strategic firm decisions about process and product developments, stimulating a search for more cost-effective approaches to pollution control.

\section{E. COMPARISONS}

How does the tax provided for in the Act on the Pollution of Surface Waters compare with other emission taxes? Although several international studies concern market oriented instruments in environmental policy (Baumol and Oates, 1979; Bower et al., 1981; Ewringmann and Schafhausen, 1985; Vos and Opschoor, 1988; Opschoor and Vos, 1989), few deal with overtly regulatory tax systems. ${ }^{8}$ Where emission taxes do exist, they primarily have a financing function-that is, to finance public treatment installations, or, as in Japan, to finance payments for pollution-related health problems-and most such taxes are too low to have a substantial regulatory effect. Hungary's tax on several kinds of water pollution apparently is meant to have a regulation impact, but little is known about the actual functioning of this system. The Japanese tax on $\mathrm{SO}_{2}$ emissions may have had a strong regulative effect: ground concentration levels of $\mathrm{SO}_{2}$ fell by more than half after the introduction of the tax, while in the same period fossil fuel consumption more than doubled (OECD, 1977, p60; Ewringmann and Schafhausen, 1985: 174-182). ${ }^{9}$ Japanese effluents to water, 
however, have not been taxed; measured in terms of oxygen demand, they have not declined much, in contrast with the striking decline in Dutch water pollution. Interestingly, Japan is now a world leader in $\mathrm{SO}_{2}$-emissions reducing technologies, while the Dutch have a strong position in water treatment equipment. In West Germany, a water emissions tax system, modified in the 1980s (see Treunert, 1987), builds on the experiences of existing "Verbände" for regional water quality and quantity control (see Klevoric and Kramer, 1973; Bower et al., 1981). The German system, however, employs pollution charges primarily to help enforce a system of regulation by individual permits. If firms reduce emissions toward or below the level specified by the permit, they are granted reductions in both the amount of emission taxes and in the tax rate (the amount per unit emitted). Also, expenditures on abatement equipment can be subtracted fully from these taxes. Tax reductions thus "subsidize" the cost of complying with permits. In contrast, the Dutch system, which also uses permits, relies more fully on the regulatory effects of the tax; it reduces taxes equally for all emission reductions, regardless of permit terms-which arguably is more economically efficient for society as a whole.

In England and Wales, responsibility for water quality and drinking water supply was given to local water authorities in the 1970s, with the costs of treatment facilities to be recouped by charges to emitters and water users. After an initial period of improvement (see Hawkins, 1984; Vogel, 1986), water quality in England now seems to be deteriorating again. In the British scheme, unlike the Dutch system, the costs of water clean-up are financed partly through charges to water users. Also, the British water authorities, unlike the Waterschappen, may dispose of their contaminants outside of their jurisdictions without charge. Both factors have led to lower charges on British industry, diminishing the charges' effectiveness in controlling primary emissions, and allowing local purification authorities to do a superficial job. ${ }^{10}$ In consequence, while English rivers are relatively clean, the contaminated sludge from treatment facilities is dumped into the seas. "

Based on these comparisons and the literature surveyed, the Dutch taxes on industrial discharges of waste water seem to be the most successful current example of regulatory emissions taxes in environmental policy, with the Japanese air pollution and the Hungarian water pollution taxes, possibly, as competitors.

\section{REGULATING MANURE, TAXING FODDER}

With direct industrial emissions curbed and remaining industrial and household emissions processed in public treatment plants, the quality of Dutch surface waters improved dramatically in the 1970s and early 1980s. A new threat, however, arose from the rapidly growing agricultural sector. Dutch 
animal producers were more efficient than competitors in Belgium and other European countries. Linked to the Port of Rotterdam by an excellent inland-transport system, they benefitted from lower imported fodder prices, from economies of scale (high numbers of pigs and chickens per firm, concentrated in small areas), and from improvements in quality control. Between 1970 and 1985, the number of cows in Holland rose from 1.9 to 4.7 million and pigs from 5.5 to 14 million (CBS, 1975 and 1986). Imports of fodder increased from 3.6 to 10 million tons a year. Arable farming also increased substantially. Annual sugar beet production rose from 4.7 to 6.3 million tons in 1985 , and potato production from 3.3 to 4.7 (CBS, 1986). ${ }^{12}$

On a per hectare basis, Dutch farmers use far more nutrients-the sum of fertilizer and manure-than those in any other country. For example, using nitrogen in chemical fertilizer alone as the measure of nutrients applied, the Netherlands averages $250 \mathrm{~kg} \mathrm{~N}$ per hectare as compared with 24 in the U.S., (OECD, 1987). Another $120 \mathrm{~kg} \mathrm{~N}$ comes from imported fodder that reaches the Dutch soil in the form of manure. The inflow of nutrients, in fact, far exceeds what growing plants can absorb. Some of the excess (especially phosphorus) accumulates in the soil. Some, mainly ammonia, is dispersed through the air and returns to the earth via precipitation, often bonded with airborne sulphur, causing acidification of soil when transformed into nitrates again. Nitrates leach into groundwater, making it unfit for drinking, and have contaminated surface waters as well. Excessive nutrient accumulations are greatest in areas with intensive animal husbandry, particularly pig and poultry raising. There trees have died, drinking water has been spoiled, and formerly abundant species in nature preserves have become sparse.

\section{A. THE ACT ON SOIL CONSERVATION (1986) AND THE ACT ON NUTRITIONAL SUBSTANCES (1986)}

In dealing with the overnutrification problem, Dutch regulation focussed primarily on excessive use of manure from intensive animal husbandry, especially pig and poultry production, even though cow manure in the aggregate is a larger source of nitrogen compound emissions, and chemical fertilizers are also important sources of pollution. After some unsuccessful temporary measures to halt the growth of the animal husbandry sector, ${ }^{13}$ the full-blown regulatory plan, embodied in the 1986 Act on Soil Conservation and the Act on Nutritional Substances, took effect in 1987. These acts impose direct limits on the amount of manure that may be applied to the soil by all kinds of farms. Depending on type of crop, only a specified amount of manure, measured in terms of phosphorus content, can be used per acre; the allowable amount declines over the next ten years. During winter, especially during frost periods, no manure can be spread. Complex 
record-keeping concerning manure production and use is required of all farms. Remarkably, the amount of chemical fertilizers used, such as phosphates and nitrates, is not regulated.

As restrictions on manure use become effective, the already existing surplus will increase, first for individual farms, but eventually for whole areas. The laws regulate disposition of the surplus, calling for detailed record keeping of sales and transportation. Unused manure may be transported to other areas where a surplus does not exist, but because of the high water content transport costs are much higher than the economic value of the manure. To facilitate transfer, provincial "manure banks" have been established. In the alternative, excess manure can be taken to manure processing plants, mainly operated by the government; these plants, it is anticipated, will concentrate the phosphorus and organic compounds in surplus manure and re-sell it, but at a loss. The plants also might concentrate nitrogen compounds for sale or convert them into harmless nitrogen gas, which can be emitted. In view of current chemical fertilizer prices such manure processing techniques are economically unattractive. The government also subsidizes farmers' investments in manure storage capacity and ammonia filters in stables.

Finally, two taxes were imposed on producers of manure, to help finance the expensive manure handling and reprocessing systems. A progressive tax is assessed on purchased fodder, increasing with the amount of fodder used per farm. A second tax is based on the number of animals per hectare over a certain base number; the tax-free base number roughly corresponds to the amount of manure that the farmer is permitted to spread on his soils. This amount, it appears, is high enough to exempt most dairy farming from the tax.

In sum, the acts combine direct regulatory restrictions on the use and disposal of a pollution-generating substance-maximum manure use per hectare, and regulations on disposal of the surplus-with progressive taxes on production units (cows, pigs, chickens) and raw materials (purchased fodder). In contrast to the water pollution charge scheme, however, this use of market-oriented regulatory mechanisms is not likely to have a substantial effect on aggregate emissions.

\section{B. WHY THE MANURE GETS DEEPER}

By focussing solely on manure (to the exclusion of chemical fertilizers), the laws deal with only part of the over-nutrification problem. Many crops are harmed if manure is spread on their leaves. Hence manure is generally applied before or just after sowing, not so much as to fertilize the plants directly but to improve the soil structure. In their fast-growing phase, plants extract some nutrients derived from manure, but not rapidly enough, so farmers typically add chemical fertilizers, often several times, when the plants are above ground. Consequently, even if the current legislation met 
with perfect compliance, the impact on overnutrification and related pollution would not be great. Emissions from chemical fertilizer will not change. The location of emissions from manure will change, diminishing acidification and over-nutrification in especially polluted areas. But emissions may increase in other, relatively clean areas. Only that part of the manure processed in an appropriate manner will reduce total emissions.

Furthermore, as might be expected of a program that seeks to regulate 100,000 farmers, ensuring compliance with the controls on manure use and manure sales is difficult. Enforcement is entrusted to the General Inspectorate of the Department of Agriculture, an agency traditionally responsive to the highly organized Dutch farming community. Objecting to timeconsuming compulsory bookkeeping and reports concerning manure use and disposal, farmers have engaged in collective destruction of prescribed forms and lobbied successfully for changes in recording requirements. In consequence, official verification of farmers' entries concerning use and trading is virtually impossible. Current estimates are that bookkeeping entries cover only about half of the actual manure stream. Control on the correctness of even these entries is nearly impossible. Maize fields, used as a source of fodder, provide a handy method of evasion. Most dairy farmers in Holland also raise some of their own fodder; maize has been one of the fastest growing crops in recent years, replacing more nutrient-efficient grasses. Maize grows in (and helps conceal) any concentration of manure. In areas with many animals, maize fields clearly have been used to dispose of excess manure.

The other set of regulatory instruments, the taxes on farm animals and purchased fodder, also focus on only one set of inputs that may lead to pollution, omitting artificial chemicals, and placing a large part of the burden on a narrow segment of the animal husbandry industry-larger pig and poultry producers. Political considerations have undoubtedly played a role in this regard, weakening the legitimacy of the program. Although the aggregate amount of manure produced by Dutch cows far exceeds that from hogs and chickens ${ }^{14}$ the progressive tax on animals per hectare and on purchased fodder is especially burdensome for pig and poultry farmers. On dairy farms the number of cows generally does not exceed 3.5 per hectare (1.5 per acre) and the number of cows per farm typically is around 60 . Moreover, dairy farmers, unlike larger pig and poultry farmers, generally raise at least some of their own fodder. Because of their offensive odors and more visible localized environmental impacts, intensive pig and poultry farms caught the public's attention more than other sources of pollution. Organized national environmental groups have publicly criticized intensive animal husbandry on ethical as well as environmental grounds and have lobbied for governmental programs to reduce production in that sector and improve animal welfare.

In addition, pig and poultry farmers had some special political disadvantages. The corporatist structure of Dutch society is overtly present in the 
agricultural sector. Dutch farmers are highly organized. Producer collectives, organized along religious, regional and product lines, perform a variety of functions, such as marketing, dissemination of technological developments via "study clubs", and representation in the major Dutch political parties. As latecomers to Dutch agriculture, the intensive animal husbandry farmers have been characterized by lower social status, educational level and capital reserves. Some rapidly growing pig and poultry farms, moreover, had broken away from the Dutch tradition of small family farms that operate with little hired labor; these corporate "superfarms," until now only dominant in egg production, are regarded with suspicion by the agricultural community. Some agricultural groups even advocate their abolition by law. The Dutch Department of Agriculture has been of little help. Concerned about increasing levels of meat production in an already saturated European market, it had little objection to environmental regulations that might curtail output in the animal husbandry sector somewhat.

The progressive taxes bear heavily only on intensive pig and poultry farms with few hectares and many animals. Manure production by dairy cattle and less crowded pig farms is not likely to be deterred. The current tendency toward larger, more intensive farms may be diminished. But the overall incentives to curtail animal husbandry and manure production do not appear to be large enough to produce significant overall environmental improvements.

Overall, therefore, Department of the Environment officials whom we have interviewed do not expect the legislation to have a great effect on the total of manure use, nor on emissions from manure, except as the result of some manure processing in treatment facilities (which have become operational only on an experimental scale). Reductions in some areas will be partially offset by increased pollution in other areas to which manure is transported. Environmental officials are pleased only that the Department of Agriculture, in helping formulate the legislation, had to publicly acknowledge the seriousness of the problem and begin work on it.

\section{CONCLUSION: THE FEASIBILITY OF EMISSION TAXES}

In The Netherlands, market-oriented regulatory methods to control industrial water pollution have been very effective, contradicting the assumption that emissions taxes, despite their theoretical appeal, are politically and administratively infeasible. On the other hand, the Dutch regulations aimed at reducing eutrophication and acidification from agricultural sources, despite their partial reliance on potentially regulatory taxes, probably will not be nearly as successful. What, then, can we conclude about the circumstances under which financially-oriented regulatory instruments are likely to be feasible? Two sets of conditions seem 
important, the first political and administrative, the second relating to technical problems.

\section{A. POLITICS AND ADMINISTRATION}

Some of the political conditions favorable to adoption of effluent taxes are suggested by comparing the Dutch policy making process to the very different one in the United States. The U.S. Congress enacted a major water pollution control program in 1972, only a few years after the Act on the Pollution of Surface Waters. Unlike the Dutch law, however, the federal Clean Water Act did not impose charges on industrial, household, or municipal effluents. Industrial emissions were to be controlled by permits specifying limits on particular pollutants derived from control agencies' assessments of the "best available" clean-up technologies (Marcus, 1980).

The Clean Water Act led to enormous investments in pollution control, spurred in part by the threat of heavy civil penalties against violators of permit terms and other regulations. But negotiations over the terms of individual permits often were contentious and protracted, at least partly because the Clean Water Act, in sharp contrast with the Dutch effluent charges, appeared to suppress consideration of variation in clean-up costs and environmental effects in deciding what technology to install in different factories. Not infrequently, compliance was delayed by litigation concerning the legal or technological propriety of abatement requirements, and by political counter-attacks by industry, protesting the alleged unreasonableness of regulatory demands (Vogel, 1986; Bardach and Kagan, 1982). While the federal government has funded 90 percent of many public treatment plants, it has used general revenues, not, like the Dutch, the proceeds of effluent charges on industry and households. Unlike the Waterschappen, American municipalities-including those with treatment plants-face no effluent charges that reflect their contribution to water pollution that affects downstream municipalities.

Why did the Americans, in contrast with the Dutch, decline to employ market-oriented regulatory strategies? The reasons are not easy to specify with confidence, and our remarks here necessarily are speculative. One political obstacle to pollution taxes, as noted earlier, stems from their flexibility and sensitivity to economic concerns, which leads to different levels of environmental protection in different areas. Politicians often prefer uniform nationwide emission limits, which provide protection from charges of "giving in" to particular industrial polluters by allowing them to pay taxes rather than reducing effluents. In a small, extremely tradedependent nation like The Netherlands, however, questions of economic efficiency were more easily and legitimately brought to bear on pollution control policy than in the U.S., with its huge internal market and, at least in 1972 , its optimism about industry's ability to absorb the costs of regulatory compliance. 
Secondly, the corporatist Dutch political structure, as compared with the more politically fragmented American political system, made it easier to approach pollution control as a technical (rather than a political) problem and to build consensus around a solution recommended by governmental experts in finance, water management, and pollution control. The Dutch Act on the Pollution of Surface Waters, unlike the federal Clean Water Act in the United States, was proposed after a decade of study by a respected government agency with a long tradition of highly competent water management and research. In the Dutch parliamentary system, the assertion of interests is (for the most part) filtered through political party leaders and formally recognized religiously- and ideologically-based organized "peak associations" of labor unions and industry organizations, which engage in behind-closed-doors bargaining and policy debate under the auspices of high level civil servants (Lijphart, 1968).

In the American political system, with its separation of powers, fragmented political parties and lack of formal mechanisms for incorporating industry in decision making, the policy debate concerning water pollution, as for other regulatory problems, was conducted both more openly, within legally-specified procedures, and more emotionally. (See Kelman, 1981; Badaracco, 1985; Brickman et al., 1985; Vogel, 1986.) The federal government in the U.S. had previously been rather inactive in water pollution control. Policy formulation was not dominated by respected government technical experts. Environmental advocacy groups, often animated by a populist, anti-business philosophy (McCann, 1986), played a large role in shaping the debate and lobbying; such groups, at that time, were nearly non-existent in The Netherlands. Politically ambitious Democratic legislators and their staffs, antagonistic toward Republic President Nixon, took the lead in framing the legislation (Marcus, 1980). Uncompromising environmental rhetoric often was employed in hearings and press conferences (Wilson, 1980). The Act was passed over the President's veto. The American legislation, in sum, was framed in a political structure far less conducive to support for flexibie.market-oriented policies than the more closed, expertise-and-compromise-oriented Dutch political system.

On the administrative level, the American framers of the Clean Water Act, in contrast with their Dutch counterparts, faced the problem of implementing a law throughout a giant continent dotted with thousands, not hundreds, of significant water pollution sources. And they could not rely on institutions like the Waterschappen, respected local agencies with a long tradition of effective water basin management. Indeed, in the U.S., federal action had been justified by the alleged laxity of state environmental agencies. But in the United States, the federal government still had to rely on the state agencies to implement the law. With a less trustworthy administrative apparatus to monitor emissions, the prescription of control technologies may have seemed a better strategy than effluent charges, with their need for constant monitoring. From this perspective, the availability of respected local agencies, with a tradition of taxing and monitoring activities, 
was a key ingredient in making effluent charges seem feasible in The Netherlands.

Even in The Netherlands, with its more propitious political and administrative structure, the enactment of the effluent charge system depended on several legitimacy building decisions. First, as pointed out earlier, although the framers of the Act on Pollution Surface Waters intended the effluent charges to create the crucial incentives for industrial pollution reduction, the charges were formally established as a fee for public water treatment services provided to individual customers. Second, the charges applied to households and public treatment facilities as well as to industry, dampening any implication that they were "anti-business". On the other hand, cooperation of the chief implementing organizations, the Waterschappen, was assured by exempting their constituency, farmers, from permit requirements and effluent charges, except in rare instances.

The significance of building political support for pollution taxes is underlined by the difficulties The Netherlands has experienced with respect to the other regulatory program, control of agricultural pollution. Its legitimacy was weakened by unequal application: the taxes on polluting inputsanimals and fodder-bear heavily on highly intensive pig and poultry farms, virtually exempting most dairy farmers. Also, the taxes have no direct and clearly visible relation to emissions. And the direct regulations on manure use, by exempting artificial fertilizer, another main source of emissions, seem to impose unequal and unjustifiable burdens on only some polluting enterprises or activities. Whereas industry, not feeling unjustly singled out, generally did not oppose water pollution taxes, some Dutch farming sectors, feeling discriminated against, have remained recalcitrant with respect to the manure control program.

At the administrative level, the program for limiting manure use and taxing fodder and animals is implemented by the central government's Department of Agriculture. When farmers, the agency's primary constituency, protested reporting and record-keeping requirements, the Department bent to their wishes, undercutting the enforceability of the environmental regulations. Conversely, in administering the industrial pollution regulations, the Waterschappen bore direct financial responsibility for operating waste water cleaning facilities and for their polluting emissions to waters under responsibility of other agencies. Thus the Waterschappen, dominated politically by agricultural interests, had little inclination to accede to unjustified industry complaints or delaying maneuvers.

\section{B. TECHNICAL DIFFICULTIES}

The two Dutch programs also differ at the technical level, suggesting two preconditions for effective pollution tax programs.

First, emissions, or polluting inputs, must be monitorable in a noncumbersome manner. In the industrial pollution case, a flat tax was imposea on a single, measurable output ${ }^{15}$-contaminated waste water, 
measured in terms of its oxygen demand. From each industrial installation, there generally were not more than a few points from which waste water was discharged into surface water or sewers. Continuous analysis techniques, including automatic metering devices, were available to measure oxygen demand at such discharge points, and to do so at reasonable costs. Finally, the number of polluting industrial firms was relatively small, and they tended to be larger enterprises, capable of financing and "debugging" new control processes and monitoring devices.

In contrast, environmentally harmful emissions from manure and chemical fertilizers spread on farms are virtually impossible to monitor and hence to tax. Emissions of manure, for example, are highly variable, depending on type of stable, stable cleaning method, storage system, and processing method. When applied to the soil, emissions depend on the technique of application, time of year, type of soil, type of crop, stage of crop, weather conditions, and emission-reducing activities, such as watering fields or plowing them immediately after spreading manure. Emissions take many forms and directions. Phosphates attach to soil particles, sometimes leach into groundwater, and run off into ditches and canals. Organic nitrogen compounds decompose slowly in the soil. Nitrates, which are more soluble, reach groundwater, ditches, and canals. Ammonia mainly evaporates into the air. The mix of these different forms of emissions is highly variable, depending on circumstances and activities of particular farmers. And of course, emissions occur irregularly, at countless points, on each of a hundred thousand farms.

The impossibility of monitoring emissions redirected regulation to the control of potentially polluting inputs. Regulations sought to limit the amount of manure that could be spread per hectare, although compliance proved difficult to monitor because of the large number of farms, the complexity of record-keeping required of small enterprises, and the ease with which excess manure could be used surreptitiously. Taxes were imposed not on emissions but on purchases of fodder and the number of animals per hectare. These factors are more susceptible to accurate monitoring, especially because farms with less animal-intensive operations were exempted. But this constriction of the tax base, as noted above, raised questions of discrimination, weakening the legitimacy of the program.

Secondly, the empirical relationship. between taxed emissions or inputs, on one hand, and environmental harm, on the other, must be relatively clear and simple. Although oxygen demand in waste water, as defined (and redefined) in the Act on the Pollution of Surface Waters, is not a perfect indicator, there is a more or less linear relation between increases in oxygen demand and degradation of water quality. For that reason, taxing oxygen demand not only facilitated monitoring, but was intellectually acceptable to industry, giving regulated entities guidance as to the economics of investment in control technologies and other emissions reducing processes.

In contrast, there is no clear and simple relationship between the 
spreading of manure and environmental harm, except in extreme cases, such as direct dumping into surface waters. Emissions from manure, as noted above, affect the environment variably. They also vary with the amount of chemical fertilizer used in the fields. "Nitrogen efficiency of crop", one (negative) measure of how much fertilizer escapes into the environment, ranges between 20 and 90 percent, depending on many agricultural factors. This complex linkage undermines the legitimacy of regulating or taxing the spreading of fertilizer (and especially manure only) on a uniform basis, ignoring variations in the environmental effects. The problem is aggravated when the tax is pushed one step further back in the production process and is levied not on the spreading of manure but on activities correlated with manure production, that is, the purchase of fodder and the number of animals in intensive animal husbandry.

In sum, from a technical standpoint, the ideal domain of emissions taxes seems to be larger, closed-process installations, as in the chemical industry or electrical power plants, where emissions flow out through a limited number of monitorable pipes or smoke stacks. Conversely, like emissions from manure, fugitive air pollution from hundreds of pipes and vents in steel plants or oil refineries can be roughly estimated but are difficult to monitor precisely enough for taxing purposes. Similarly, solid waste from households, or even non-homogenous wastes from industry and office buildings, are so diverse that it is difficult to separate out and monitor, and hence tax, environmentally problematic substances.

\section{EXPANDING THE FRAMEWORK: TAXES ON INPUTS, REFUNDS FOR EMISSIONS REDUCTION}

Two lessons of the preceding sections are, first, that to enhance prospects of winning the necessary political support, emissions taxes should be broadbased and not obviously discriminatory; and second, that they should be enforceable, which tends to limit them to particular industries. The two criteria push in different directions. The wider the tax base, the more difficult the enforcement problem; the more narrowly the program focusses on particular, easily monitorable enterprises, the more likely it will, justly, be perceived as discriminatory.

When monitoring emissions is difficult, as in the case on manure on Dutch farms, it is tempting to tax inputs (such as fodder), because purchases (or sales) of pollution prone materials may be easier to monitor. The difficulty with that strategy was that the linkage between inputs and pollution was variable, and especially unfair to those that did a better job of controlling emissions or disposing of manure in non-polluting ways.

Unfortunately, the kind of environmental problem posed by agricultural pollution in The Netherlands-in which environmental degradation stems from the gradual cumulation of small, difficult to monitor emissions from many thousands of individual sources-is far from unique. Some of the 
most pressing environmental problems-acid rain, ozone layer depletion from chlorofluorocarbons, excessive production of carbon dioxide, buildup of heavy metals in soil-stem from thousands of low visibility sources, like motor vehicles and home furnaces, degreasing agents and product surface treatments, refrigerators, and air conditioners. Financially-oriented regulatory instruments may eventually play a role in dealing with such collective problems. The lesson to be drawn from the Dutch tax on fodder and animals is not that taxes on polluting inputs cannot work, but that they must be refined. One direction that refinement might take is as follows, although the concept here is sketched only with broad strokes.

The political difficulty with the Dutch manure related taxes, we saw, was that they were too narrowly targetted, omitting inputs like chemical fertilizers and exempting manure producing dairy farms, the largest emitters of ammonia. In principle, however, taxes on polluting inputs, such as nitrogen and phosphorus compounds (not simply on fodder by weight), could be extended to cover nearly all such compounds produced or imported into a nation. As charges on production and importation of pollution-prone chemicals, the administrative difficulties would be less than those associated with collecting taxes on emissions.

The problem of taxes on inputs, we have seen, is their uncertain link with environmentally harmful emissions. Suppose, however, one shifted the burden of establishing (or disproving) that link to users of the polluting inputs. That could be done, in principle, by allowing users to recover a portion of the original taxes on inputs. To do so, the users would have to monitor the ultimate disposition of the substances and prove that they have not entered the environment in a harmful way. That is, by proving that pollution has not occurred, one could earn a refund of the tax on that portion of the inputs.

In the case of agricultural pollution, for example, a tax could be imposed on all major sources of nitrogen and phosphorus compounds that flow into the nation, whether in the form of domestically produced or imported chemical fertilizers or imported fodder. The tax presumably would be passed on in price increases to intermediate and ultimate purchasers. Any user, waste handler, manufacturer, farmer, or exporter who can demonstrate that he has either exported, processed or disposed of such a compound in an environmentally harmless way could receive a pro-rata tax refund. Incentives would be generated throughout the system to devise private monitoring and emission-reducing (refund-enhancing) techniques or to switch to less polluting (tax saving) inputs. The broad based nature of the tax-it could even encompass other uses of phosphorus, as in washing powder-would enhance its political feasibility.

Much remains to be done, of course, in developing the specifics of such $\operatorname{tax} /$ refund schemes and the types of substances for which they would be technically feasible. But the final lesson of the Dutch experience with emission taxes, in our view, is that the search for financially-oriented 
regulatory instruments clearly has emerged from the economist's study into the realm of politically feasible action. Their further development is far more likely than not.

GJALT HUPPES (1946) studied political and economic sciences at the University of Amsterdam. He has been attached to the Centre for Environmental Studies of the State University Leiden for over a decade. Publications cover the fields of environmental analysis of products, analysis of hazardous substances, planning and policy design.

ROBERT A. KAGAN is Professor of Political Science and Law at the University of California, Berkeley. Author of numerous books and articles on regulatory agencies and courts, his current research concerns cross-national differences in labor law, environmental law, and liability law as they affect the operation of seaports and intermodal transportation.

\section{NOTES}

1. See Liroff (1986) and Hahn (1986) for a recent assessment.

2. See Baumol and Oates (1979) for a description of some cases. Ewringmann and Schafhausen (1985) survey market-oriented legislation in Eastern and Western European countries, Vos and Opschoor (1988) and Opschoor and Vos (1989, in print) survey policy instruments with market elements in OECD countries. Bower et al. (1981) assess French and West German charges for water quality control, concluding that those charges had no practical regulative effect, because direct regulatory standards imposed emission reduction costs that far exceeded the level of effluent charges.

3. Ammonia, often bound to airborne sulphuric acid, is transformed into nitrate in the soil, releasing acid in the process.

4. Personal communication to us from workers in the industry. Strawboard is a packaging material made of straw and recycled paper.

5. In the beginning of the 1970 s, only $25 \%$ of discharges from Dutch municipal systems were partially cleaned, as compared to $85 \%$ in Great Britain, where surface water is the primary source of drinking water; in The Netherlands, utilities extract most drinking water from groundwater percolating through sandy soils.

6. Only one member of parliament voted against the Act, because the position of the Waterschappen, in his opinion, was not yet strong enough.

7. As a multi-national enterprise, Gist-Brocades might, in principle, compare the effects of environmental policies the firm is subject to in different countries. Generally, Gist-Brocades officials told us, their total costs incurred in response to environmental policies in other countries, such as France, Italy and West Germany, have been similar to those incurred in The Netherlands. Since the emission reductions in The Netherlands have been so large, one might assume that the Dutch system was extremely cost-effective, but the integration of pollution control with process-improving investments makes any calculation impossible. And Gist-Brocades officials were unable to compare the environmental improvements stemming from their expenditures in different countries.

8. Ewringmann and Schafhausen, 1985, discuss 33 different systems of emissions taxes. 
9. In 1976 the Japanese tax level was around $\$ 0.60$ per $\mathrm{kg} \mathrm{S} \mathrm{emitted} \mathrm{to} \mathrm{air} \mathrm{in} \mathrm{heavily}$ polluted areas. The Dutch tax on $\mathrm{N}$-compounds emitted to water, as part of the tax on oxygen demanding substances, is around $\$ 0.90$ per $\mathrm{kg} \mathrm{N}$.

10. The water authorities in England and Wales will be privatized in 1989, along with both their tasks-waste water treatment and drinking water production. It may be expected that the bias towards easily collected drinking water tariffs will continue, and the charge on effluents will be too low to have a substantial, regulative effect. Emissions directly to surface waters will not be charged at all.

11. In a recent international conference on North Sea pollution (London, November 1987), the English clearly were the culprits as far as dumping is concerned. Their rivers, however, transport less of many hazardous substances into the North Sea than comparable rivers in W. Germany and Belgium, like the Elbe and Schelde, even if the sludge the British dump into the sea is included. Rivers ending in The Netherlands, the Rhine and the Meuse, are the mixed responsibility of many countries.

12. A recent publication of the Central Bureau of Statistics, CBS (1988b), states that by 1988 The Netherlands' 16,480 square miles (about one third the size of Pennsylvania) were home to 4.7 million cows, 14 million pigs (about the same number as human residents), 1.2 million sheep, and 90 milion chickens.

13. A temporary measure, the Interim Act on Intensive Animal Husbandry (1985), prohibited growth of existing farms and introduction of new farms in areas in which pig and poultry production was linked to environmental problems. But pig and poultry farming continued to accelerate. Fearing more stringent controls under the planned permanent regulations, some producers seem to have taken the temporary ban as a cue to increase production. The governmental authorities charged with combatting expansion, municipalities in areas with intensive animal husbandry, are strongly influenced by farmers' concerns. Contrary to the rules, permits were allowed in nearly all cases. Litigation by environmental groups to enforce compliance with the law was initiated in only a few cases. This was not due to lack of funds, for such advocacy groups are subsidized by the Dutch government. The leader of such a provincial group told us that litigation would have impaired social relations with the farmers for a long time, while producing only limited environmental gains. In the long run, he felt, a cooperative attitude might be more constructive.

14. The distribution of biomass in the Netherlands, a proxy for manure produced, is as follows, in thousands of tons: cows 1,400; humans 1,000; pigs 700 ; other (chicken, horse, sheep) 100.

15. Some Waterschappen also charge for heavy metals in effluents, but that charge is relatively low.

\section{REFERENCES}

BARDACH, E. and R. A. KAGAN (1982) Going By The Book: The Problem of Regulatory Unreasonableness, A Twentieth Century Fund Report. Philadelphia: Temple University Press.

BAUMOL, W. J. and W. E. OATES (1979) Economics, Environmental Policy, and The Quality of Life. Englewood Cliffs, N.J.: Prentice-Hall.

BOWER, B. T., J. KUHNER and C. S. CLIFFORD (1981) Incentives in Water Quality Management: France and the Ruhr Area. Washington, D.C.: Resources for the Future.

BRESSERS, J. T. A. (1983) Beleidseffektiviteit en Waterkwaliteitsbeleid. PhD, Enschede. 
BRESSERS, J. T. A. (1988) "A Comparison of the Effectiveness of Incentives and Directives: The Case of the Dutch Water Quality Policy," Policy Studies Review 7: 500-518.

BRICKMAN, R., S. JASONOFF and T. ILGEN (1985) Controling Chemicals: The Politics of Regulation in Europe and the United States. Ithaca, N.Y.: Cornell University Press.

CBS (1975) 75 Jaar Statistiek van Nederland. The Hague: Staatsuitgeverij.

CBS (1976 and 1986) Statistisch Zakboek. The Hague: Staatsuitgeverij.

CBS (1988a) "Kosten-effectiviteit van Biologische Afvalwaterzuivering bij Bedrijven," Kwartaalbericht Milieustatistieken 5: 4-8.

CBS (1988b) Meitelling. The Hague: Staatsuitgeverij.

EWRINGMANN, D. and F. J. SCHAFHAUSEN (1985) Abgaben als Okonomischer Hebel in der Umweltpolitik. Berlin: Schmidt Verlag.

HARFORD, J. and S. OGURA (1983) "Pollution Taxes and Standards: A Continuum of Quasi-optimal Solutions," Journal of Environmental Economics and Management 10: 1-17.

HAWKINS, K. (1984) Environment and Enforcement: Regulation and the Social Definition of Pollution. Oxford: Oxford University Press.

KELMAN, S. (1981) Regulating America, Regulating Sweden: A Comparative Study of Occupational Safety and Health Regulations. Cambridge, Mass.: MIT Press.

KLEVORICK, A. K. and G. H. KRAMER (1973) "Social Choice on Pollution Management: the Genossenschaften," Journal of Public Economics 2: 101-146.

LiJPhART, A. (1968) The Politics of Accommodation: Pluralism and Democracy in the Netherlands. Berkeley, Cal.: University of California Press.

LIROFF, R. A. (1986) Reforming Air Pollution Regulation: The Toil and Trouble of EPA's Bubble. Washington, D.C.: The Conservation Foundation.

LOURENS, P. A. (1987) “The Waste Water Sanitation Program of Gist-Brocades NV Location Delft," in K. J. De Waal and W. J. Van Den Brink (Eds.) Environmental Technology. Dordrecht: Nijhoff.

MARCUS, A. (1980) "Environmental Protection Administration," in J. Q. Wilson (Ed.) The Politics of Regulation. New York: Basic Books.

McCANN, M. (1986) Taking Reform Seriously: Perspectives on Public Interest Liberalism. Ithaca, N.Y.: Cornell University Press.

OECD (1987) OECD Environmental Data. Paris: OECD.

OECD (1977) Environmental Policies in Japan. Paris: OECD.

OPSCHOOR, J. B. and J. B. VOS (1989) Economic Instruments of Environmental Policy in OECD Member Countries. Paris: OECD.

schuurman, J. (1988) De Prijs Van Water. PhD Leiden Univ. Arnhem: Gouda Quint.

TREUNERT, E. (1987) "Die Neuen Regelungen des Abwasserabgabengesetzes," Kommunale Entsorgung 1987: 20-25.

vOS, J. B. and J. B. OPSCHOOR (1988) "Marktconforme Instrumenten voor Milieubeleid in OESO-Landen," in G. Huppes et al. (Eds.) Instrumenten voor Milieubeleid. Alphen aan den Rijn: Samsom.

WILSON, J. Q. (1980) The Politics of Regulation. New York: Basic Books. 
HeinOnline -- 11 Law \& Pol'y 2401989 